\title{
ARE EMOTIONALLY INTELLIGENT PEOPLE MORE EMOTIONALLY STABLE? AN EXPERIENCE SAMPLING STUDY
}

\author{
D. LYUSIN ${ }^{\mathrm{a}, \mathrm{b}}$, A.-R. MOHAMMED \\ ${ }^{a}$ National Research University Higher School of Economics, 20 Myasnitskaya Str., Moscow, 101000, \\ Russian Federation \\ ${ }^{b}$ Institute of Psychology, Russian Academy of Sciences, 13 build. 1, Yaroslavskaya Str., Moscow, 129366, \\ Russian Federation
}

\begin{abstract}
The temporal dynamic characteristics of mood play an important role in various aspects of our lives, including our psychological health and well-being. It is assumed that individuals with high emotional intelligence (EI) are characterized by more positive and stable moods. However, most studies analyze how EI is related to emotional traits or momentary assessments of mood, hence not much is known about the relationship of EI to mood dynamics. The present study aimed at answering the following questions: How are dynamic characteristics of mood related to each other? To what extent are they independent? Which aspects of EI are related to particular characteristics of mood dynamics? Participants filled out an EI questionnaire and then reported their mood three times daily for two weeks. Mean mood scores calculated across all measurement points were regarded as static characteristics showing a mood background typical for the participant. Also, three dynamic characteristics of mood were calculated, namely variability, instability, and inertia. Mood variability and instability have been found to be very closely related to each other but not to inertia. Higher EI is related to more enduring mood states, i.e., higher mood inertia and a higher stability of the tension dimension of mood. Unlike previous studies that measured only static mood characteristics, no relationship between higher EI and positive mood have been found. Some aspects of EI were related to the inertia of negative and positive moods. The results show that experience sampling provides new insights on the role of EI in mood.
\end{abstract}

Keywords: emotional intelligence, mood dynamics, mood variability, mood instability, mood inertia.

\section{Introduction}

Emotions are fleeting phenomena and this is fundamental to their nature. Davidson, who coined the term "affective chronometry" (Davidson, 1998), emphasized the importance of studying the dynamic characteristics of emotions for a better

The study was implemented in the framework of the Basic Research Program at the National Research University Higher School of Economics (HSE) in 2018. 
understanding of affective disorders and psychological health and well-being (Davidson, 2015). Contemporary approaches to emotion, be they appraisal, evolutionary, or constructivist theories (Moors, 2014; Tracy, 2014; Barrett, 2014), underline the dynamic nature of emotions. Mood temporal dynamics play a critical role in psychopathology and important for the diagnostic of some psychiatric disorders such as bipolar disorders (American Psychiatric Association, 2013). However, most experimental studies take a static perspective on emotions understanding them either as the states unchanging during certain periods of time or as traits (Kuppens, 2015).

Recently, more research has appeared showing the important role of the dynamic characteristics of mood in various aspects of our lives. It has been shown that emotion dynamics are related to a wide array of psychological characteristics including psychological health, well-being (Houben, Van Den Noortgate, \& Kuppens, 2015), and the development or recovery of mood disorders (Wichers, Wigman, \& Myin-Germeys, 2015).

In this article we concentrate on the possible relationships between mood dynamics and emotional intelligence (EI), which generally refers to the understanding and management of one's own and others' emotions. The ability to understand and control one's own emotions is vital to psychological well-being (Houben et al., 2015). It is assumed that individuals high in EI are characterized by more positive and stable moods. Most studies exploring this issue analyze how EI is related to emotional traits or momentary assessments of mood; there are almost no findings on the relationship between EI and mood dynamics.

The dynamic characteristics of mood are most often obtained through experience sampling, repetitive systematic self-reports over time. Typically, participants are asked to report their moods several times per day for several days or weeks. This method provides rich data that can be analyzed in different ways. The most popular dynamic characteristics include emotional variability, emotional instability, and inertia (Houben et al., 2015).

Emotional variability refers to the amplitude of an individual's mood changes. It shows how far or close an individual's mood is in relation to their average values. A person with high emotional variability would be characterized by experiencing emotions at extreme levels and would have greater mood deviations from the average mood level. Emotional variability is usually calculated as a within-person standard deviation of mood across time.

Emotional instability refers to the extent to which mood varies from one occasion to another. This is distinct from emotional variability in the sense that an individual characterized by a higher level of instability experiences greater mood shifts from one moment to the other, whereas emotional variability concerns only the amplitude of the changes. Therefore, emotional instability and variability are conceptually different although positive correlations between these variables can be expected. The emotional instability index can be calculated as the mean squared successive difference (MSSD) involving consecutive emotional states.

Emotional inertia denotes the prediction of a current mood state based on a previous mood state. An individual with a higher level of emotional inertia is charac- 
terized by experiencing emotions that are more enduring. This is usually calculated using the autocorrelation of mood states across time.

There are quite a number of studies that have examined the relationship between EI and mood using different approaches. Although they usually analyzed only static emotional traits or momentary moods, these studies provided many valuable results. In many studies, momentary mood or mood as a trait was measured with the Positive Affect and Negative Affect Schedule (PANAS, Watson, Clark, \& Carey, 1988), whereas EI was measured with different questionnaires and tests. In spite of the diversity of EI measures, the results are reasonably consistent.

Saklofske, Austin, Mastoras, Beaton, and Osborne (2012) used an emotional intelligence questionnaire EQI (Bar-On, 2002) and the PANAS. All the five subscales of the EQI were positively correlated with positive mood (correlation coefficients ranging from .21 to .56) and negatively correlated with negative mood ( $r \mathrm{~s}$ from -.21 to - .57). Extremera and Rey (2016) measured ability EI with the MSCEIT (Mayer, Salovey, \& Caruso, 2002). They found a weak positive correlation between EI and the positive affect scale of the PANAS $(r=.11, p<.01)$, whereas the negative affect scale was negatively correlated with EI $(r=-.19, p<.01)$. Lyusin and Ovsyannikova (2015) assessed mood with a Russian adaptation of the PANAS (Osin, 2012) and EI with the Russian emotional intelligence questionnaire EmIn. Consistent with other results, all the EmIn scales were positively related to the positive affect ( $r$ from .27 to .40); general scores of the EmIn and the scales of intrapersonal EI and emotion management were negatively related to negative mood ( $r$ s from -.26 to - -36 ). A longitudinal study by Sánchez-Álvarez, Extremera, and Fernández-Berrocal (2015) assessed EI with the use of the Trait Meta-Mood Scale (TMMS) and mood with the PANAS on three occasions over two years. Their results showed that negative mood was positively correlated with attention to emotion ( $r$ s from .22 to .29 ) and positive mood positively correlated with mood clarity ( $r$ s from .17 to .42) and emotional repair ( $r$ s from .18 to .44).

In some studies that used the PANAS, general mood valence was assessed by affect balance calculated as the difference between the scores of positive and negative affect. For instance, Liu, Wang, and Lü (2013) measured EI with the Wong and Law Emotional Intelligence Scale (WLEIS) and found a positive correlation $(r=.40)$ between affect balance and EI. Lyusin and Ovsyannikova (2015) also found positive correlations between affect balance and the scales of general EI, intrapersonal EI, and emotion management ( $r$ s from .39 to .45).

Some studies analyzed the associations between the PANAS and Schutte's SelfReport Emotional Intelligence Scale (Schutte et al., 1998). EI was found to be positively related to positive mood $(r=.55)$, but there was no association with negative mood (Schutte, Malouff, Simunek, Hollander, \& McKenley, 2002). Another study (Koydemir, Şimşek, Schütz, \& Tipandjan, 2013) conducted in two different cultures (Germany and India) found a positive correlation $(r=.46$ and $r=.28$ respectively) between affect balance and EI, irrespective of the cultural background.

Stolarski, Jankowski, Matthews and Kawalerczyk (2016) measured mood twice, in the morning and the evening, with the use of the WIST mood adjective 
list. EI measured by the Test of Emotional Intelligence (Śmieja, Orzechowski, \& Stolarski, 2014) was found to correlate negatively with tense arousal, but this association was stronger in the evening. No other significant correlations between EI and mood were found.

To sum up, practically all studies explore the relationships of EI with only static mood characteristics. Most often, higher EI is associated with a more positive and less negative affect irrespective of what measures were used; typical correlations are low or medium. Relationships between EI and the dynamic characteristics of mood remain mostly unstudied which makes it important to apply an experience sampling procedure to mood measurement and to relate the obtained mood characteristics to EI. Experience sampling will allow the analysis of mood dynamics and assessments of the mood background typical for an individual. These assessments can be regarded as analogous to mood traits measured with questionnaires but they are more valid since they are based not on a momentary retrospective selfreport but on repetitive self-reports over time.

The present study aimed to analyze the relationships between EI and mood dynamics. We used an experience sampling procedure and measured participant EI having two research questions in mind. (1) How are the characteristics of mood dynamics related to each other and to what extent are they independent? (2) Which aspects of EI are related to particular characteristics of mood dynamics? Although this study was exploratory in nature, we still had some expectations. First, people with higher EI should experience more positive and less negative moods. Secondly, the mood of emotionally intelligent people should be more stable and enduring; this association will be stronger for intrapersonal EI.

\section{Method}

\section{Participants}

Twenty-seven undergraduate students (all female) from Moscow, with age ranging from 17 to 21 years $(\mathrm{M}=18.32, \mathrm{SD}=1.02)$ participated in the study for a course credit. One participant was excluded from the analysis because she did not fill out all the questionnaires thus reducing the final sample to 26 participants.

\section{Measures}

Participant momentary mood was assessed with the emotional state questionnaire EmoS-18 (Lyusin, 2014). This is a Russian-language self-report measure consisting of 18 words that represent such mood states as happiness, enthusiasm, sadness, regret, agitation, tension, etc. The participants are asked to rate their mood with the use of these words on the Likert scales from 1 to 5. The EmoS-18 questionnaire is based on an empirically obtained three-dimensional model of mood. It comprises three scales (6 words for each), Positive Mood with High Arousal, Negative Mood with Low Arousal, and Tension with Cronbach's alphas of .84, .88, and .87 , respectively. 
EI was measured with the EmIn Questionnaire, a Russian self-report measure (Lyusin, 2006). It consists of 46 items with a 4-point Likert scale response format, from "completely disagree" to "completely agree". These items form four questionnaire scales: Interpersonal EI (e.g., "I understand other people's inner states without words"), Intrapersonal EI (e.g., "I know what to do to improve my mood"), Emotion Comprehension (e.g., "Often, I can't find the words to describe my feelings to my friends"), and Emotion Management (e.g., "If I hurt somebody's feelings, I don't know how to restore a good relationship with them"). The aggregate score of these scales provides the assessment of General EI. The Cronbach's alphas of the EmIn scales were reported to range from .84 to .89 (Lyusin \& Ovsyannikova, 2015).

\section{Procedure}

A meeting with participants was organized to give instructions and to explain how to fill out the questionnaires. The participants were asked to fill out the EmoS-18 questionnaire three times a day for a two-week period. They were told to implement the first measurement of mood in the morning right after waking up, the second measurement in the middle of the day, and the last one at night before going to bed. Another meeting was organized a week later to discuss the progress made and to offer assistance on challenges they may have encountered during the process. At any moment participants could contact experimenters via email. Some participants completed the EmIn questionnaire during the first meeting, others during the second meeting.

\section{Results}

All the participants successfully followed the instructions and generally succeeded in reporting their mood for two weeks three times a day. Twelve participants implemented the procedure for 14 days, 11 participants for 13 days, 1 participant for 12 days, and 2 participants for 6 days. The average percentage of skipped measurement points across participants was $5 \%$, ranging from 0 to $18 \%$.

The results of one participant are presented in Figure 1. It shows how the three dimensions of mood measured by the EmoS-18 were changing over time.

\section{Analysis of Mood Characteristics}

The experience sampling procedure gave an array of mood characteristics for each participant, both static and dynamic. They were calculated separately for all three scales of the EmoS-18, namely Positive Mood with High Arousal (PM-HA), Negative Mood with Low Arousal (NM-LA), and Tension. Mean scores for each scale calculated across all measurement points can be regarded as the static characteristics showing a mood background typical for the participant. Variability scores were calculated as standard deviations; MSSD was used as an index for instability; inertia scores were calculated as first-order autocorrelations. The descriptive statistics are presented in Table 1. 
Results of Mood Measurement with the Use of Experience Sampling Procedure (Participant 9)

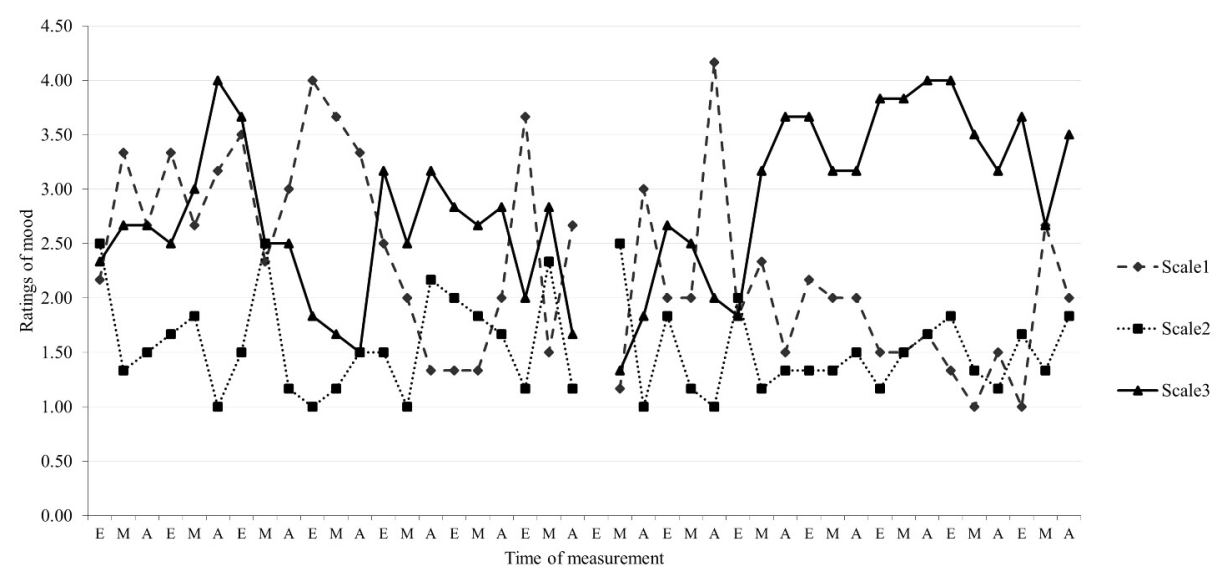

Note. E - Evening, M - Morning, A -Afternoon, Scale 1 - Positive Mood with High Arousal, Scale 2 - Negative Mood with Low Arousal, Scale 3 - Tension.

Table 1

Descriptive Statistics for Static and Dynamic Mood Characteristics Based on the Experience Sampling Procedure

\begin{tabular}{|l|c|c|c|c|}
\hline \multicolumn{1}{|c|}{ Measure } & Min & Max & Mean & Std. Deviation \\
\hline Mean PM-HA & 1.38 & 3.69 & 2.26 & 0.58 \\
\hline Mean NM-LA & 1.07 & 2.74 & 1.69 & 0.46 \\
\hline Tension & 1.30 & 3.65 & 2.10 & 0.50 \\
\hline Variability: PM-HA & 0.39 & 1.42 & 0.84 & 0.25 \\
\hline Variability: NM-LA & 0.10 & 1.34 & 0.72 & 0.33 \\
\hline Variability: Tension & 0.28 & 1.42 & 0.69 & 0.27 \\
\hline Instability: PM-HA & 0.21 & 3.93 & 1.24 & 0.95 \\
\hline Instability: NM-LA & 0.02 & 3.39 & 0.91 & 0.86 \\
\hline Instability: Tension & 0.10 & 2.53 & 0.79 & 0.71 \\
\hline Inertia: PM-HA & -0.12 & 0.61 & 0.20 & 0.19 \\
\hline Inertia: NM-LA & -0.24 & 0.84 & 0.20 & 0.25 \\
\hline Inertia: Tension & -0.14 & 0.74 & 0.27 & 0.23 \\
\hline
\end{tabular}

Note. PM-HA - Positive mood with high arousal (Scale 1 of the EmoS-18), NM-LA - Negative mood with low arousal (Scale 2 of the EmoS-18). 
Table 2 provides a summary of the inter-correlations between all mood characteristics. Mean PM-HA and mean NM-LA (Scales 1 and 2 of the EmoS-18) are independent $(r=-.02)$ whereas Tension (Scale 3$)$ correlates positively with other scales, especially with NM-LA $(r=.67)$. Variability scores for all three scales of the EmoS-18 positively correlate with each other ( $r$ s range from .43 to .63 ); the same holds for instability ( $r$ s from .67 to .80 ) and inertia ( $r$ s from .22 to .30 ) scores.

Of particular interest are correlations among variability, instability, and inertia scores because it is important to evaluate their degree of independence. Notably, there are high positive correlations between the variability and instability scores across all three EmoS-18 scales ( $r$ s from .87 to .92) which means that these two variables double each other and measure essentially the same construct. As a dynamic characteristic, instability seems to be more preferable than variability since it reflects moment-to-moment changes in mood whereas variability shows only the amplitude of mood changes. For these reasons, variability was excluded from the subsequent analysis.

An analysis of the relationships between static and dynamic mood characteristics shows that,

(1) mean PM-HA positively correlates only with the instability (and variability) of PM-HA;

(2) mean NM-LA positively correlates with the instability (and variability) of all mood scales, but correlations with the instability (and variability) of NM-LA are the highest;

(3) mean Tension positively correlates with the instability (and variability) of all mood scales without any obvious preferences;

(4) there are almost no high correlations (and only one significant correlation) with inertia.

This correlation pattern further confirms the idea that variability can be excluded from the analysis since it doubles instability whereas inertia is a characteristic distinct from instability and variability.

\section{Static and Dynamic Mood Characteristics and Emotional Intelligence}

The relationships between the obtained mood characteristics and EI are presented in Table 3. There are no significant relationships between static mood characteristics (that is, mean positive mood with high arousal, mean negative mood with low arousal and mean tension) and any scales of the EmIn questionnaire.

Significant relationships between dynamic mood characteristics and EI are scarce but informative. There are two correlations that are significant at the conventional level of $\mathrm{p}<.05$, a correlation of .389 between the inertia of PM-HA and Interpersonal EI and a correlation of .46 between the inertia of NM-LA and Emotion Understanding. Also, there are two correlations with $p \mathrm{~s}<.10$, a correlation between the inertia of NM-LA and General EI $(r=.37, p=.06)$ and a correlation between the inertia of NM-LA and Interpersonal EI ( $r=.386, p=.051)$. 
$\frac{\text { है }}{\stackrel{\Xi}{\Xi}}$

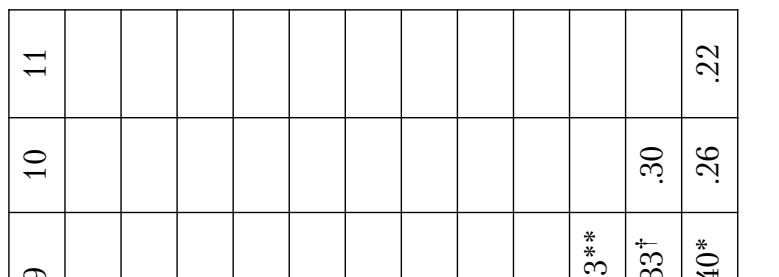

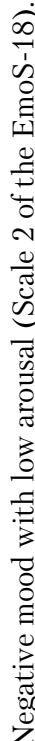

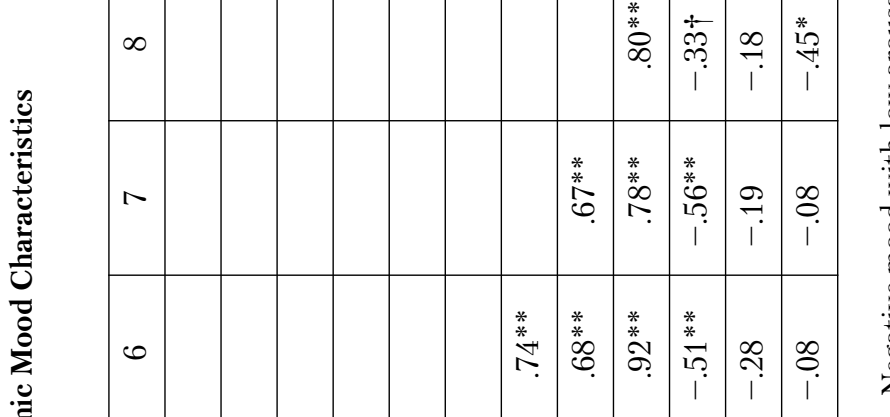

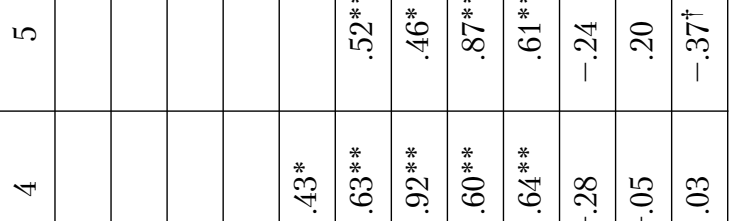

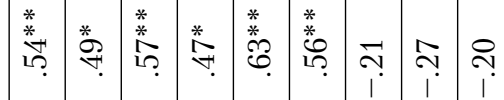

$\infty$

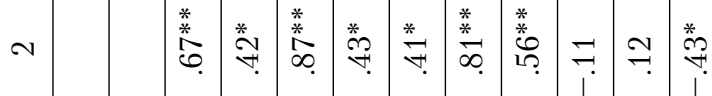

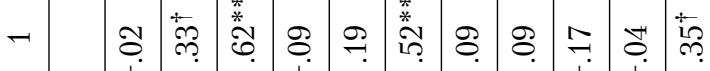

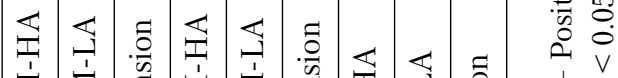

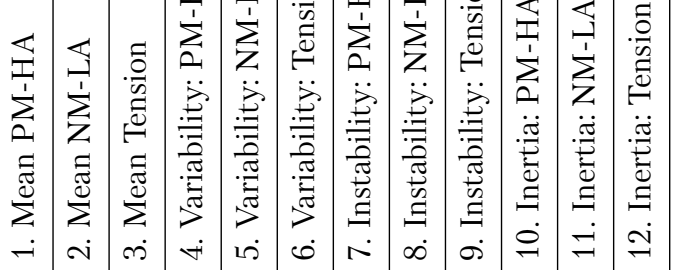

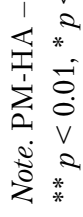


Table 3

Correlations between Static and Dynamic Mood Characteristics and Emotional Intelligence

\begin{tabular}{|l|c|c|c|c|c|}
\hline & $\begin{array}{c}\text { General } \\
\text { EI }\end{array}$ & $\begin{array}{c}\text { Intrapersonal } \\
\text { EI }\end{array}$ & $\begin{array}{c}\text { Interpersonal } \\
\text { EI }\end{array}$ & $\begin{array}{c}\text { Emotion } \\
\text { understanding }\end{array}$ & $\begin{array}{c}\text { Emotion } \\
\text { management }\end{array}$ \\
\hline 1. Mean PM-HA & .14 & -.04 & .29 & .09 & .16 \\
\hline 2. Mean NM-LA & .15 & .05 & .20 & .13 & .12 \\
\hline 3. Mean Tension & .14 & .02 & .22 & .02 & .22 \\
\hline 4. Instability: PM-HA & -.09 & -.06 & -.10 & -.06 & -.10 \\
\hline 5. Instability: NM-LA & .02 & .00 & .03 & .06 & -.02 \\
\hline 6. Instability: Tension & -.28 & -.16 & -.32 & -.30 & -.19 \\
\hline 7. Inertia: PM-HA & .26 & .07 & $.389^{*}$ & .30 & .16 \\
\hline 8. Inertia: NM-LA & $.37 \dagger$ & .26 & $.386 \dagger$ & $.46^{*}$ & .19 \\
\hline 9. Inertia: Tension & .03 & -.09 & .15 & .12 & -.07 \\
\hline
\end{tabular}

Note. PM-HA - Positive mood with high arousal, NM-LA - Negative mood with low arousal. ${ }^{* *} p<0.01,{ }^{*} p<0.05,{ }^{\dagger} p<0.10$.

\section{Discussion}

The first research question concerned the degree of independence among the calculated mood dynamic characteristics: emotional variability, instability, and inertia. We found that mood variability operationalized as a within-person standard deviation of mood across time and mood instability operationalized as MSSD were closely related to each other and yielded very similar correlation patterns with other variables. Therefore, they measure essentially the same construct. We consider instability to be a more adequate dynamic characteristic of mood, since it reflects moment-to-moment changes in mood. Interestingly, some studies do not distinguish between variability and instability and use MSSD as an index of variability (e.g., Bowen, Baetz, Hawkes, \& Bowen, 2006). Mood inertia was found to be a distinct characteristic of mood dynamics independent of mood variability and instability.

The second research question concerned relationships between EI and static and dynamic mood characteristics. Static mood characteristics were calculated as mean scores for each scale of the EmoS-18 across all measurement points. None yielded any significant correlations with the EmIn scales. This finding is inconsistent with previous studies that reported significant relationships between mood and EI (Extremera \& Rey, 2016; Liu, Wang, \& Lü, 2013; Sánchez-Álvarez, Extremera, \& Fernández-Berrocal, 2015). This unusual result can be attributed to the fact that static mood indices were calculated as the average mood within the two-week period. It is possible that in other studies, where mood and EI were typically measured once, participants reported their current mood and level of EI more or less at the same time which could provide spurious correlations. Hence, if 
their current mood was more positive they rated their EI higher. On the other hand, participants were likely to report low EI when they were experiencing a negative mood.

The absence of significant correlations between EI and the usual background mood obtained with the use of experience sampling raises doubts about the seemingly established consensus on the relationships between mood and EI based on research using a different methodology.

We expected to find relationships between dynamic mood characteristics and EI. A more precise prediction claimed that the mood of emotionally intelligent people would be more stable and enduring, and this association would be stronger for intrapersonal EI. Few significant correlations were found. It is important to bear in mind that the sample size was limited which resulted in a low statistical power. For explorative purposes, we interpret the results taking into account marginally significant correlations $(p<.10)$. This type of analysis allows us to see what should be explored more closely in the future studies with a higher statistical power.

The inertia of PM-HA and NM-LA correlates positively with many aspects of EI, first of all with interpersonal EI and emotion understanding. It can be suggested that higher EI helps maintain emotional states in terms of valence but not in terms of activation level. Contrary to our expectations, interpersonal EI plays a more important role in mood inertia compared to intrapersonal EI. Probably, social interactions are more successful or at least more predictable in individuals with higher interpersonal EI (and higher emotion understanding) and this helps them to maintain a smoother mood.

The instability of mood yielded no statistically significant correlations with EI; however, the instability of tension achieves the correlation coefficient of -.32 with interpersonal EI which is rather high, not only for this study but also for other studies in the field. We find it important to concentrate on this relationship in future research since people with higher EI may turn out to be more stable in terms of emotional tension.

To sum up, the experience sampling procedure implemented in this study enabled us to obtain static and dynamic characteristics of mood and to analyze their relationships with each other and with EI. The findings suggest that higher EI can be related to more enduring mood states, i.e., higher mood inertia, and higher stability of the tension dimension of mood. The main limitation of the study is the small sample size resulting in a low statistical power. More significant and informative correlations between EI and mood could be found in future studies with a higher statistical power. All the participants of the present study were female, and it remains unclear to what extent the findings would be similar for male participants. Our study suggests ways to improve the methodology for similar studies. Among many of them, here are the two most obvious. First, more measurement points per day are desirable for a more fine-grained analysis of mood dynamics. Second, assessments of the mean mood based on experience sampling should be compared to momentary mood assessments directly in the same study; this will help to understand the contradictory results concerning relationships between static mood characteristics and EI. In general, the results show that the analysis of mood dynamics based on experience sampling provides new important insights on the role of EI in mood. 


\section{References}

American Psychiatric Association. (2013). Diagnostic and statistical manual of mental disorders (5th ed.). American Psychiatric Pub. doi:10.1176/appi.books.9780890425596.744053

Bar-On, R. (2002). Bar-On Emotional Quotient Inventory: Short. Technical manual. Toronto, ON: Multi-Health Systems.

Barrett, L. F. (2014). The conceptual act theory: A prücis. Emotion Review, 6, 292-297. doi:10.1177/1754073914534479

Bowen, R., Baetz, M., Hawkes, J., \& Bowen, A. (2006). Mood variability in anxiety disorders. Journal of Affective Disorders, 91(2), 165-170. doi:10.1016/j.jad.2005.12.050

Davidson, R. J. (1998). Affective style and affective disorders: Perspectives from affective neuroscience. Cognition and Emotion, 12(3), 307-330. doi:10.1080/026999398379628

Davidson, R. J. (2015). Comment: Affective chronometry has come of age. Emotion Review, 7(4), 368 370. doi:10.1177/1754073915590844

Extremera, N., \& Rey, L. (2016). Ability emotional intelligence and life satisfaction: Positive and negative affect as mediators. Personality and Individual Differences, 102, 98-101. doi:10.1016/j.paid.2016.06.051

Houben, M., Van Den Noortgate, W., \& Kuppens, P. (2015). The relation between short-term emotion dynamics and psychological well-being: A meta-analysis. Psychological Bulletin, 141(4), 901-930. doi:10.1037/a0038822

Koydemir, S., Şimşek, Ö. F., Schütz, A., \& Tipandjan, A. (2013). Differences in how trait emotional intelligence predicts life satisfaction: The role of affect balance versus social support in India and Germany. Journal of Happiness Studies, 14(1), 51-66. doi:10.1007/s10902-011-9315-1

Kuppens, P. (2015). It's about time: A special section on affect dynamics. Emotion Review, 7(4), 297 300. doi:10.1177/1754073915590947

Liu, Y., Wang, Z., \& Lü, W. (2013). Resilience and affect balance as mediators between trait emotional intelligence and life satisfaction. Personality and Individual Differences, 54(7), 850-855. doi:10.1016/j.paid.2012.12.010

Lyusin, D. (2006). Novaya metodika dlya izmereniya emotsional'nogo intellekta: oprosnik EmIn [A new measure for emotional intelligence: EmIn Questionnaire]. Psikhologicheskaya Diagnostika, 4, 3-22. (in Russian)

Lyusin, D. (2014). Opyt razrabotki samootchetnoy metodiki dlya otsenki emotsional'nykh sostoyaniy [A self-report measure for assessment of emotional states]. In V. T. Kudryavtsev (Ed.), Myshleniye i rech: Podkhody, problemy, resheniya [Thinking and speech: approaches, problems, and decisions]. Proceedings of the 15th Vygotsky readings (Vol. 1, pp. 140-143). Moscow: Lev. (in Russian)

Lyusin, D., \& Ovsyannikova, V. V. (2015). Relationships between emotional intelligence, personality traits and mood. Psychology Journal of the Higher School of Economics, 12(4), 154-164. (in Russian)

Mayer, J. D., Salovey, P., \& Caruso, D. (2002). Mayer-Salovey-Caruso emotional intelligence test (MSCEIT). Version 2.0. Toronto, ON: Multi-Health Systems.

Moors, A. (2014). Flavors of appraisal theories of emotion. Emotion Review, 6(4), 303-307. doi:10.1177/1754073914534477

Osin, E. N. (2012). Measuring positive and negative affect: development of a Russian-language analogue of PANAS. Psychology. Journal of the Higher School of Economics, 9(4), 91-110. (in Russian)

Saklofske, D. H., Austin, E. J., Mastoras, S. M., Beaton, L., \& Osborne, S. E. (2012). Relationships of personality, affect, emotional intelligence and coping with student stress and academic success: 
Different patterns of association for stress and success. Learning and Individual Differences, 22(2), 251-257. doi:10.1016/j.lindif.2011.02.010

Sánchez-Álvarez, N., Extremera, N., \& Fernández-Berrocal, P. (2015). The relation between emotional intelligence and subjective well-being: A meta-analytic investigation. The Journal of Positive Psychology, 9760, 1-10. doi:10.1080/17439760.2015.1058968

Schutte, N. S., Malouff, J. M., Hall, L. E., Haggerty, D. J., Cooper, J. T., Golden, C. J., \& Dornheim, L. (1998). Development and validity of a measure of emotional intelligence. Personality and Individual Differences, 25(2), 167-177. doi:10.1016/S0191-8869(98)00001-4

Schutte, N. S., Malouff, J., Simunek, M., Hollander, S., \& McKenley, J. (2002). Characteristic emotional intelligence and emotional well-being. Cognition and Emotion, 16, 769-785. doi:10.1080/02699930143000482

Śmieja, M., Orzechowski, J., \& Stolarski, M. S. (2014). TIE: An ability test of emotional intelligence. PLoS ONE, 9(7). doi:10.1371/journal.pone.0103484

Stolarski, M., Jankowski, K. S., Matthews, G., \& Kawalerczyk, J. (2016). Wise "birds" follow their clock: The role of emotional intelligence and morningness-eveningness in diurnal regulation of mood. Chronobiology International, 33(1), 51-63. doi:10.3109/07420528.2015.1115413

Tracy, J. L. (2014). An evolutionary approach to understanding distinct emotions. Emotion Review, 6(4), 308-312. doi:10.1177/1754073914534478

Watson, D., Clark, L. A., \& Carey, G. (1988). Positive and negative affectivity and their relation to anxiety and depressive disorders. Journal of Abnormal Psychology, 97, 346-353. doi:10.1037/0021843X.97.3.346

Wichers, M., Wigman, J. T. W., \& Myin-Germeys, I. (2015). Micro-level affect dynamics in psychopathology viewed from complex dynamical system theory. Emotion Review, 7, 363-367. doi:10.1177/1754073915590623

Dmitry Lyusin - Lead Research Fellow, National Research University Higher School of Economics, Senior Research Fellow, Institute of Psychology, Russian Academy of Sciences, PhD. Research Area: psychology of emotion, emotional information processing.

Email: ooch@mail.ru

Abdul-Raheem Mohammed - PhD Student, National Research University Higher School of Economics.

Research Area: executive functions, emotion regulation, interaction between emotion and cognition.

Email: arm.raheem@gmail.com 


\title{
Связан ли эмоциональный интеллект с эмоциональной устойчивостью? Результаты исследования, основанного на регулярных самоотчетах
}

\author{
Д.В. Люсин ${ }^{\mathrm{a}, \mathrm{b}}$, А.-Р. Мохаммед \\ ${ }^{a}$ Национальный исследовательский университет «Высшая школа экономики», 101000, Россия, \\ Москва, ул. Мясниикая, д. 20

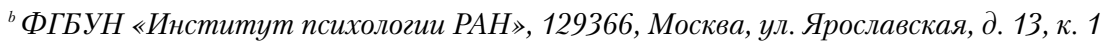

\section{Резюме}

Динамика настроения играет важную роль в разных аспектах жизни, включая психологическое здоровье и благополучие. Принято считать, что людям с высоким эмоциональным интеллектом (ЭИ) свойственно более положительное и устойчивое настроение. Однако большинство исследований анализируют связь ЭИ лишь с эмоциональными чертами или текущим настроением, в то время как связь ЭИ с динамикой настроения оказывается мало изученной. Цель настоящего исследования состояла в том, чтобы выяснить, как динамические характеристики настроения связаны друг с другом, в какой степени они являются независимыми и какие аспекты ЭИ связаны с теми или иными динамическими характеристиками настроения. Испытуемые заполняли опросник на ЭИ и затем на протяжении двух недель три раза в день давали самоотчет о своем настроении. Средние оценки настроения, усредненные по всем замерам, рассматривались как статические характеристики настроения, отражающие типичный для испытуемого эмоциональный фон. Также оценивались три динамические характеристики настроения - вариативность, неустойчивость и инерционность. Показатели вариативности и неустойчивости оказались тесно связаны друг с другом, но слабо коррелировали с инерционностью. Высокий ЭИ оказался связан с большей инерционностью настроений, иначе говоря со склонностью испытывать более длительные эмоциональные состояния, и с большей устойчивостью такого измерения настроения, как напряжение. В отличие от предыдущих исследований, учитывавших только статические характеристики настроения, не было получено связи более высокого ЭИ с положительным настроением. В целом результаты свидетельствуют о том, что регулярные замеры настроения позволяют получить принципиально новые сведения о связи ЭИ с настроением.

Ключевые слова: эмоции, ядерный аффект, структура эмоциональных состояний.

Люсин Дмитрий Владимирович - ведущий научный сотрудник, Национальный исследовательский университет «Высшая школа экономики»; старший научный сотрудник, Институт психологии РАН, кандидат педагогических наук, доцент.

Сфера научных интересов: психология эмоций, переработка эмоциональной информации. Email: ooch@mail.ru

Абдул-Рахим Мохаммед - аспирант, Национальный исследовательский университет «Высшая школа экономики».

Сфера научных интересов: управляющие функции, эмоциональная регуляция, взаимодействие между эмоциями и познавательными процессами.

Контакты: arm.raheem@gmail.com 